Proc. Estonian Acad. Sci. Geol., 1999, 48, 4, 213-227

\title{
DOLOMITES OF THE MUHU FORMATION (SILURIAN) IN MAINLAND ESTONIA: ASPECTS OF DOLOMITIZATION, PROPERTIES, AND PROSPECTS OF UTILIZATION
}

\author{
Aada TEEDUMÄE, Tarmo KIIPLI, and Toivo KALLASTE
}

Institute of Geology, Tallinn Technical University, Estonia pst. 7, 10143 Tallinn, Estonia; teedumae@gi.ee

Received 24 March 1999, in revised form 14 June 1999

\begin{abstract}
In mainland Estonia the Muhu Formation of the Jaagarahu Stage (Silurian, Wenlock) is represented by secondary dolomites (dolostones) originating from the normal-marine calcareous sediments of the shoal facies belt of the palaeobasin. Five rock types, reef, breccia, microcrystalline, low-argillaceous, and argillaceous dolomites, differing in the lithological composition, properties, and possible fields of use, are distinguished.

The chemical composition of dolomites exhibits close to ideal molar proportions of $\mathrm{Ca}$ and $\mathrm{Mg}$ for all above-mentioned types of dolomites. The results of the X-ray diffraction study show that dolomites are nearly stoichiometric, with $d_{104}$ equalling $2.8850-2.8856 \AA$.

The dolomites studied represent the most completely and evenly dolomitized part of the extensive body of pervasive Silurian dolomites.
\end{abstract}

Key words: Silurian, dolomitization, lithology, Palaeozoic dolomite, XRD analysis, mineral resources.

\section{INTRODUCTION}

The beds corresponding to the present Muhu Formation (Silurian, Wenlock) were distinguished by Luha (1930) as the lithostratigraphic unit "Dolomitkomplex von Muhu und Kesselaid", subsequently included into the provisionally established Muhu-Kurevere Stage (Luha, 1933), later to the Jaagarahu Stage (Luha, 1946). The lithostratigraphical classification of the present Jaagarahu Stage has been changed recurrently (e.g. Aaloe, 1970; Aaloe et al., 1958, 1976), some additional units have been introduced (Resheniya..., 1987; Nestor, 1995), and the Muhu dolomites by Luha (1930) have been re-established as a formation (Nestor, 1995). 
The present study of the aspects of dolomitization of the Muhu Formation is based on comparative analysis of the chemical composition and X-ray diffractometry of 10 samples (K1-K10) collected by A. Teedumäe in 1998 from Kurevere quarry and on the results of chemical analyses of the geological exploration of the Anelema (Remmel, 1969) and Kurevere (Korbut, 1993a) deposits.

The generalized characterization of different rock types is based on about 200 analyses and tests of samples consisting of only one certain rock type. The analyses and tests were selected from all performed in the course of geological prospectings and explorations and deposited in the Estonian Geological Fund (EGF). For the characterization of the impact of dolomitization on porosity, the material of the Koonga deposit was used, as the chemical composition and porosity have been analysed from the same sample in this deposit only (Remmel, 1974).

This study was carried out within the framework of the research project 0140226 "Lithological-mineralogical preconditions for the rational use of bowels of the earth in Estonia". It also constitutes a sequel to the series of studies (Teedumäe, 1988, 1992, 1996) on the distribution, properties, and potential resources of the carbonate rocks of Estonia.

\section{DISTRIBUTION AND CHARACTERISTICS OF ROCK TYPES AND PROSPECTS OF UTILIZATION}

In mainland Estonia the Muhu Formation spreads north of Pärnu. It embraces the whole section and lateral extent of the Jaagarahu Stage (Fig. 1). Southwards it is replaced by the Riksu Formation. The rocks of the Muhu Formation originate from sediments formed in the northeastern marginal part of the gulf-like pericratonic sea (the "Baltic Gulf") during the middle Wenlock regression. Gradual shallowing, interrupted by short deepening episodes (Nestor \& Einasto, 1997), resulted in a great variety of shoal carbonate deposits - reefs, skeletalpelletal sand and silt, calcareous-argillaceous muds. Secondary dolomitization has destroyed skeletal remains and changed the composition of the rocks, but the lithological variety of rocks has preserved. The regressive character of the sequence is expressed in the upwards decreasing content of terrigenous material - insoluble residue (Fig. 2). The thickness of the Muhu Formation is variable (Figs. 2, 3) and everywhere incomplete due to the hiatus in late Jaagarahu time (Nestor \& Nestor, 1991) and because of post-Silurian denudation.

The outcrop of the Muhu dolomites (dolostones) has a rather thick (in general more than $5 \mathrm{~m}$ ) Quaternary cover. It is thinner only in the northern and northwestern areas where the dolomites of the lower part of the formation are exposed in quarries and ancient coastal cliffs on isolated inliers (Fig. 1).

The Muhu Formation consists of five main lithotypes of dolomite. These are of quite scattered spatial distribution because of the migration of the shoreline during Jaagarahu time. 


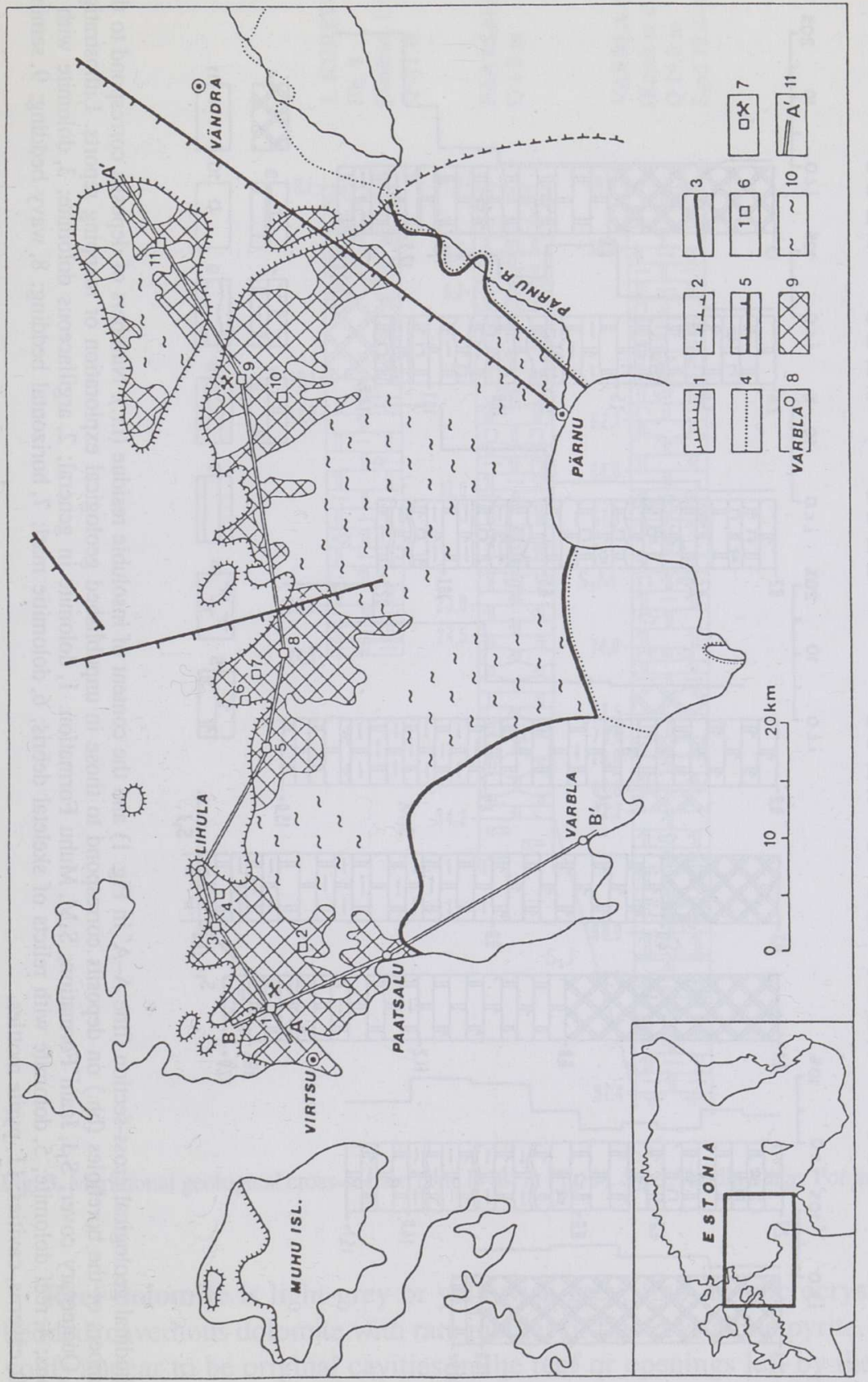

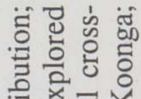
정전 $\theta 60$ 过

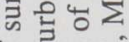
故顽 吉怘

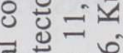
สำ 50 की के - 8 ङ

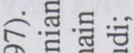
ㅇํㄹㄹㅣ 苟岁 웡 乙范完 造 की ठี छี.

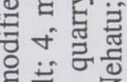
ह艹

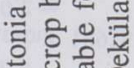

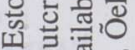
पे ट्ये ปฏ ฐึ ญี สำ

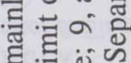
๓ें 닝 등ํㅇㅎㅣ ธี 莽

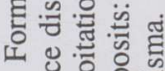
르ㄴㅠㅠ음

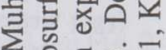

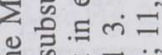
巨范范 을웜

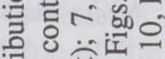
点

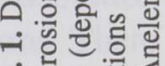

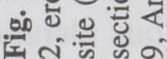


의 흐혀

舒

品

웝 혼

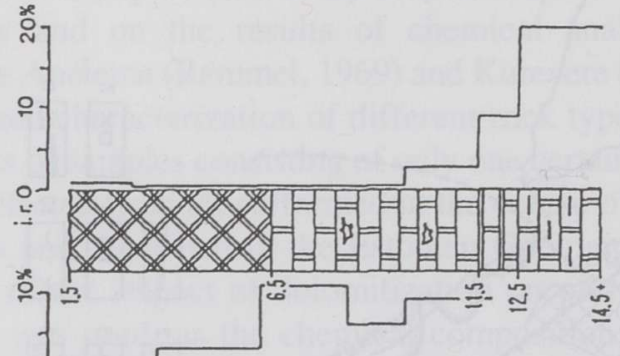

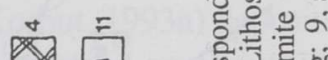

ऊु. ํㅡㅇ

u $\mathrm{s}^{\prime} \mathrm{I} \partial$

(I86I 'หе!poา)

$9 \tau$ ' Ч

FWSIVY 'II

แ1 820

(896I 'рэuшวy)

IE पघ

VWGTสNy *

uI 7.00

( 7 L6I '[ашسวy)

g 062 ' 4

YDNOOY 8

u $\tau \cdot 00$

(qع66I 'mq10X)

5 पद

VAYVI 'S

u s.0 O

(L66I

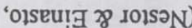

พากमIา

u

(ร66I 'gu!̣!nn」)

ISNVOd $\mathcal{1}$

u $L \tau \partial$

(I86I 'Үe!poา)

乙I 'Ч

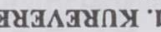

uा I I

(Еย66I 'วnqrox)

उक्षज

釒

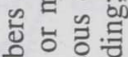

Eิ

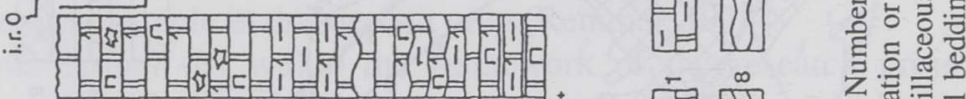

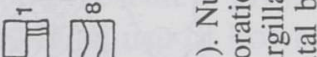

ํํㄹ을 증

4 xi.

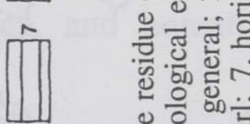

응

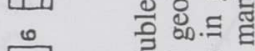
$F_{k} \quad$ 焉

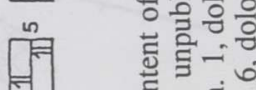

ธี.

ธ

둥

으이대

드를웜

os

证和

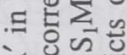

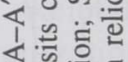

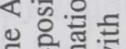
䆑要 등ํㅇ놀 일

己ั่

อ의

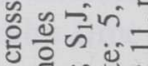

สํํㄹ

항ㅇㅇ응

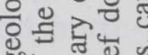

空

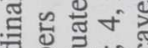

हैं के

寻艺 00

i-i i त

을

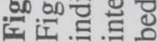



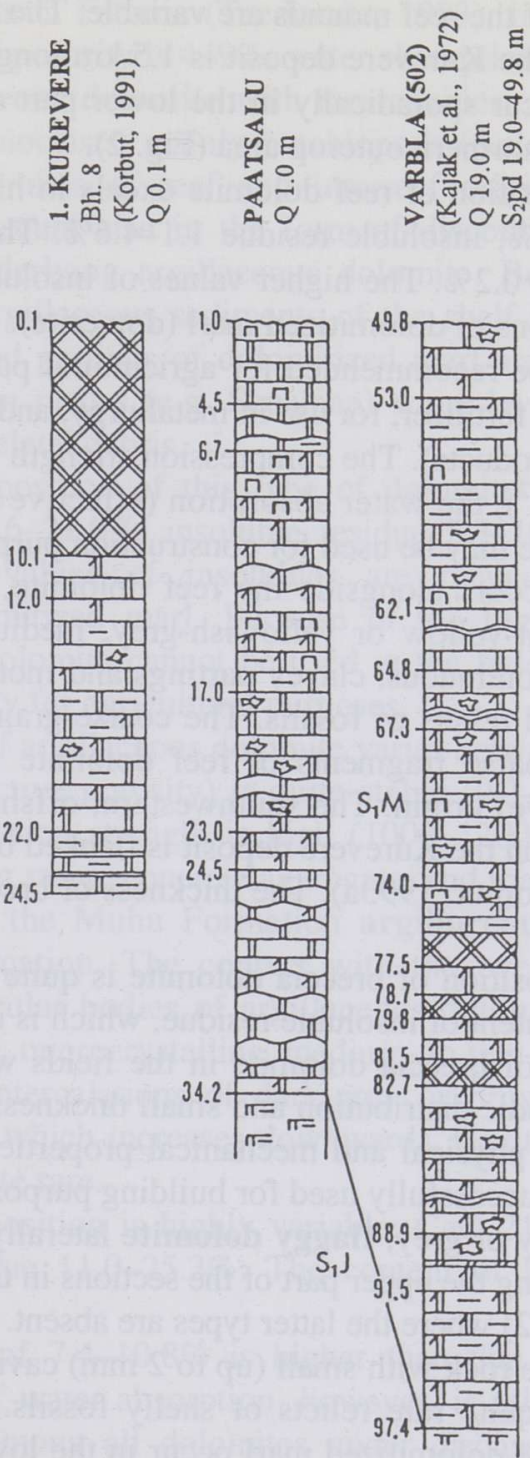

Fig. 3. Meridional geological cross-section (line B-B' in Fig. 1). $\mathrm{S}_{2}$ pd, Paadla Stage. For legend see Fig. 2.

Reef dolomite is light-grey or yellowish-grey, fine- to microcrystalline, nonbedded, cavernous dolomite with rare mottles of fine-crystalline pyrite. Some of the voids appear to be original cavities in the reef or openings left by the dissolution of fossils, others are irregular solution cavities not related to organic forms. There is no visible skeletal frame, but the texture of dolomite and relicts of tabulate and rugose corals, crinoids and other fossils (Aaloe, 1970) confirm the reef origin of 
rocks. The dimensions of the reef mounds are variable. The biggest reef mound of NW-SE orientation on the Kurevere deposit is $1.5 \mathrm{~km}$ long, $700 \mathrm{~m}$ wide, and up to $11 \mathrm{~m}$ thick. Reefs occur sporadically in the lower part of the section (Fig. 3) which is exposed in the northern outcrop area (Fig. 2).

The chemical composition of reef dolomite excels in high purity: $\mathrm{CaO} 28.6-$ $30.0 \%, \mathrm{MgO} 20.8-21.9 \%$, insoluble residue $1.1-4.6 \%$. The content of $\mathrm{Fe}_{2} \mathrm{O}_{3}$ is $0.2-0.5 \%$, mainly above $0.2 \%$. The higher values of insoluble residue are caused by rare irregular inclusions of dolomitized marl (domerite).

Reef dolomite may be recommended for agricultural purposes - for reducing the acidity of soil and as fertilizer, for use in metallurgy, and for glass manufacture (except for colourless products). The compression strength of the reef dolomite is high (1100-1300 kg/cm ${ }^{2}$ ), the water absorption (effective porosity) is low (1.5$2.0 \%$ ), and thus dolomite may be used for construction purposes.

Breccia dolomite occurs alongside the reef dolomite, forming the flanking detrital apron. It is light-yellow or yellowish-grey, medium-bedded, cavernous dolomite with thin, discontinuous, clayey partings and mottles of fine-crystalline pyrite and rare pyritized relicts of fossils. The coarse-grained relict texture with visible inclusions of coarse fragments of reef dolomite indicates its near-reef wave-generated (abrasive) origin. The southwestern, offshore side of the abovementioned biggest reef on the Kurevere deposit is flanked by the breccia dolomite throughout its extent (Korbut, 1993a). The thickness of breccia dolomite does not exceed $4 \mathrm{~m}$.

The chemical composition of breccia dolomite is quite similar to that of reef dolomite, except the content of insoluble residue, which is usually less than $2.0 \%$. This allows of the use of breccia dolomite in the fields where pure dolomite is needed. Due to its sporadic distribution and small thickness, the breccia dolomite has not been tested for physical and mechanical properties, but, visually, it is a solid rock and may be successfully used for building purposes.

Light, yellowish-grey or grey, flaggy dolomite laterally replaces the reef and breccia dolomites, forming the upper part of the sections in the areas (e.g. Anelema, Kurevere, Koonga; Fig. 2) where the latter types are absent. It is mainly a mediumbedded, microcrystalline rock with small (up to $2 \mathrm{~mm}$ ) cavities, rare spots of finecrystalline pyrite, and quite rare relicts of shelly fossils. Discontinuous clayey partings or interlayers of dolomitized marl occur in the lower part of the section. This dolomite represents an interreef rock built up of fine calcareous muds and silts derived from reef erosion and, perhaps, also from precipitation of Ca-carbonate directly from sea water. On the outcrop the thickness of flaggy dolomite varies from 2 to $8 \mathrm{~m}$.

The chemical composition of flaggy dolomite is quite close to that of reef dolomite: $\mathrm{CaO} 27.5-30.0 \%, \mathrm{MgO} 20.2-22.0 \%$, insoluble components $1.6-7.5 \%$, among them $\mathrm{Fe}_{2} \mathrm{O}_{3} 0.4-0.6 \%$. It can be used in agriculture, metallurgy, and glass manufacture (except for colourless glass).

The physical and mechanical properties correspond to those of high-quality building material. The compression strength is the highest (up to $2000 \mathrm{~kg} / \mathrm{cm}^{2}$ ) 
among carbonate rocks in Estonia (Teedumäe, 1983), being prevailingly above $1300 \mathrm{~kg} / \mathrm{cm}^{2}$. The total porosity is $4-9 \%$, water absorption less than $2 \%$.

Grey, low-argillaceous dolomite with rare cavities, spots of fine-crystalline pyrite, and relicts of bioclasts, mainly brachiopods (Aaloe, 1970), underlies the above-mentioned dolomites of reef and interreef origin. This mainly microcrystalline dolomite occurs also in the form of discontinuous layers or lenses deeper, inside the underlying argillaceous dolomite. Both dolomites originate from the calcareous-argillaceous sediments of the shelf belt. Sporadic rare thin wavy intercalations and partings of dolomitized marl are quite characteristic of the whole sequence. In places (e.g. Sepamaa) some layers of low-argillaceous dolomite are rich in skeletal debris.

The chemical composition of this type of dolomite is more variable: $\mathrm{CaO}$ 26.7-28.7\%, $\mathrm{MgO}$ 19.6-21.0\%, insoluble residue 5.3-10.2\% (incl. $\mathrm{Fe}_{2} \mathrm{O}_{3}$ 0.4$1.1 \%)$. The highest values of insolubles are related to the intervals of intercalations of dolomitized marl. Because of the high content of insoluble residue, argillaceous dolomite cannot be used in the fields where high purity is needed; it finds use only for agricultural purposes.

The total porosity of argillaceous dolomite varies between $3 \%$ and $8 \%$, but the water absorption (effective porosity) is quite stable $(0.3-3.1 \%)$ and mostly less than $2 \%$. The compression strength is high $\left(1000-1200 \mathrm{~kg} / \mathrm{cm}^{2}\right)$ and dolomite may be used as building stone, concrete aggregate, and roadstone.

On the outcrop of the Muhu Formation argillaceous dolomite forms the lower part of the formation. The contact with the overlying dolomite is not always distinct. Lenticular bodies of argillaceous dolomite occur even higher. Lithologically it is grey, microcrystalline, medium- to thin-bedded or seminodular dolomite with wavy intercalations of dark-grey or brownish-grey dolomitized marl, the frequency of which increases downwards. Cavities, pyrite mottles, and relicts of fossils are quite rare.

The chemical composition is highly variable: $\mathrm{CaO} 21.3-27.0 \%, \mathrm{MgO} 14.9-$ $20.1 \%$, insoluble residue $11.0-25.3 \%$. The content of $\mathrm{Fe}_{2} \mathrm{O}_{3}$ is $0.6-2.7 \%$, on average about $1 \%$.

The total porosity of $7.4-10.8 \%$ is higher than that of the other types of dolomite. The value of water absorption, however, is relatively low, $1.4-3.7 \%$, yet it is the highest among all dolomites under discussion. The compression strength is also highly variable $\left(800-1300 \mathrm{~kg} / \mathrm{cm}^{2}\right)$, depending on the number of thin intercalations and partings of dolomitized marl. The instability of the quality does not allow of the use of argillaceous dolomite for any known purposes except for local building.

\section{RESULTS OF ANALYTICAL STUDY}

To study the aspects of dolomitization and explain the excess of $\mathrm{MgO}$ revealed in $30-70 \%$ of chemical analyses made during geological explorations of deposits, the comparative analysis of the chemical composition and X-ray diffractometry 
of 10 samples from Kurevere quarry was performed. XRD measurements were carried out on a model HZG4 X-ray diffractometer. Dolomite stoichiometry was determined by measuring the position of the 104 peak using $\mathrm{Si}$ as a standard. No correction for the displacement of the 104 peak due to Fe-substitution was necessary because of the low iron content which is related to visible mottles and spots of iron compounds. The content of $\mathrm{CaCO}_{3}$ in dolomite was calculated as follows

$$
\mathrm{mol} \% \mathrm{CaCO}_{3}=\frac{\left(d_{104}-2.8840\right)}{0.003}+50 \text {. }
$$

The value 2.8840 for $d_{104}$ of ideal dolomite was calculated on the basis of the composition of standards Es4 (Estonia) and S1 (USSR). It corresponds well to the $d_{104}$ value of nearly,ideal dolomites measured by Reeder \& Sheppard (1984).

The X-ray results showed the $\mathrm{CaCO}_{3} / \mathrm{MgCO}_{3}$ molar ratio close to 1 (Table 1 ). This was proved by the results of chemical analyses. Of the chemical analyses made, 50\% (samples K1, K2, K3, K4, and K6) showed the excess, and another $50 \%$ (samples $\mathrm{K} 5, \mathrm{~K} 7, \mathrm{~K} 8, \mathrm{~K} 9$, and $\mathrm{K} 10$ ) revealed the deficiency of $\mathrm{MgO}$. Both values were small (Table 1) and did not exceed the precision of the method.

The $d_{104}$ values of studied dolomites (Table 1) cluster at the lower margin of the characteristic interval of normal dolomites (2.885-2.890 $\AA$ ) distinguished by

Table 1. Results of the X-ray diffractometry and chemical analyses of the dolomites of the Kurevere deposit

\begin{tabular}{|c|c|c|c|c|c|c|c|c|}
\hline \multirow[b]{2}{*}{$\begin{array}{c}\text { Sample } \\
\text { No. }\end{array}$} & \multicolumn{3}{|c|}{$\mathrm{X}$-ray diffractometry } & \multicolumn{4}{|c|}{ Titration analysis } & \multirow[b]{2}{*}{$\begin{array}{l}\text { Type of } \\
\text { dolomite }\end{array}$} \\
\hline & $d_{104}, \AA$ & $\begin{array}{c}\mathrm{CaCO}_{3}, \\
\mathrm{~mol} \%\end{array}$ & Calcite & $\underset{\%}{\mathrm{CaO}}$ & $\underset{\%}{\mathrm{MgO}}$ & $\begin{array}{c}\text { Insoluble } \\
\text { residue, } \\
\%\end{array}$ & $\begin{array}{c}\text { Excess }(+), \\
\text { deficiency }(-) \\
\text { of } \mathrm{MgO} \\
\% *\end{array}$ & \\
\hline Es4 & 2.8863 & 50.77 & $(-)$ & 29.35 & 20.47 & n.d. & n.d. & n.d. \\
\hline S1 & 2.8856 & 50.53 & $(-)$ & 29.60 & 20.80 & n.d. & n.d. & n.d. \\
\hline K1 & 2.8851 & 50.4 & $(+)$ & 29.81 & 21.90 & 1.32 & +0.44 & Reef \\
\hline K2 & 2.8850 & 50.3 & $(-)$ & 29.48 & 21.74 & 1.98 & +0.52 & Yellow flaggy \\
\hline K3 & 2.8853 & 50.4 & $(-)$ & 29.48 & 21.25 & 2.18 & +0.03 & Grey flaggy \\
\hline K4 & 2.8854 & 50.5 & $(-)$ & 29.59 & 21.41 & 1.44 & +0.11 & Yellow flaggy \\
\hline K5 & 2.8852 & 50.4 & $(+)$ & 29.48 & 21.09 & 1.92 & -0.13 & Breccia \\
\hline K6 & 2.8856 & 50.5 & $(-)$ & 29.26 & 21.41 & 2.58 & +0.35 & Yellow flaggy \\
\hline K7 & 2.8856 & 50.5 & $(-)$ & 30.03 & 21.17 & 1.34 & -0.45 & Grey flaggy \\
\hline K8 & 2.8854 & 50.5 & $(+)$ & 29.70 & 21.25 & 1.98 & -0.13 & Grey flaggy \\
\hline K9 & 2.8851 & 50.4 & $(-)$ & 30.03 & 21.49 & 1.16 & -0.13 & Reef \\
\hline K10 & 2.8856 & 50.5 & $(-)$ & 30.03 & 21.41 & 1.10 & -0.21 & Reef \\
\hline
\end{tabular}

* calculated as $\mathrm{MgO}-0.72 \times \mathrm{CaO}$. n.d., not determined. 
Kallaste \& Kiipli (1995). According to the previous studies of Palaeozoic dolomites, the $d_{104}$ value of secondary dolomites of large bodies is higher than $2.886 \AA$ (Vingisaar \& Utsal, 1978; Kallaste \& Kiipli, 1995), and the dolomites with a lower value of $d_{104}$ are considered to be of primary origin or resultant of dolomitization in restricted zones near tectonic disturbances (Vingisaar \& Utsal, 1978; Kiipli, 1983a). In this respect the studied dolomites of the Muhu Formation represent the most completely dolomitized part of the extensive body of Silurian dolomites that cross-cuts facies stretching from the eastern Saaremaa Island through entire Estonia.

There is no relationship between dolomite stoichiometry and rock type (Table 1). The molar ratio of $\mathrm{CaO} / \mathrm{MgO}$ does not depend on the content of insoluble residue (Fig. 4). It is very close to the theoretic value of 1.39 of mineral dolomite in the whole range of the Muhu Formation in mainland Estonia.

The dolomitization has rearranged, that is, levelled the total porosity. In the case of limestones of the Vasalemma Formation (Ordovician), which are comparable to the precursor carbonate of studied dolomites, there exists nearly linear correlation between the porosity and insoluble residue (Teedumäe, 1988). In the case of the Muhu dolomites, the porosity has increased, but the correlation with the content of the insoluble residue (Fig. 5) is less distinct. The total porosity of the purest rocks has increased by $4-5 \%$, that of the argillaceous dolomite by $1-2 \%$, and the dominating value of the total porosity is between $6 \%$ and $9 \%$. The low porosity is quite characteristic of massive replacement reservoirs of Palaeozoic dolomite (Purser et al., 1994).

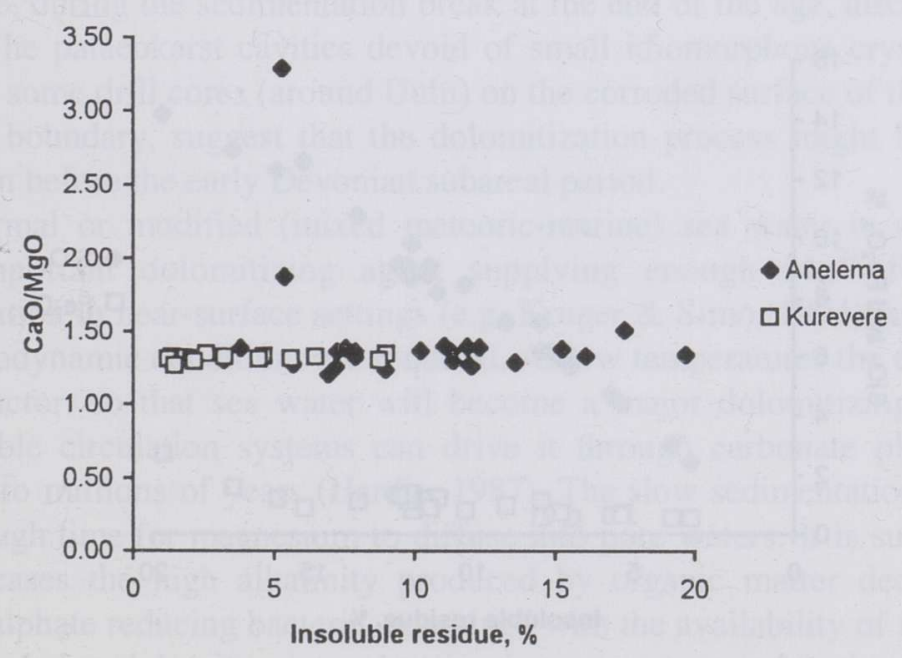

Fig. 4. Correlation of the $\mathrm{CaO} / \mathrm{MgO}$ ratio and the insoluble residue content of the dolomites of the Anelema and Kurevere deposits. Chemical analyses of the exploration reports (Remmel, 1969; Korbut, 1993a). 


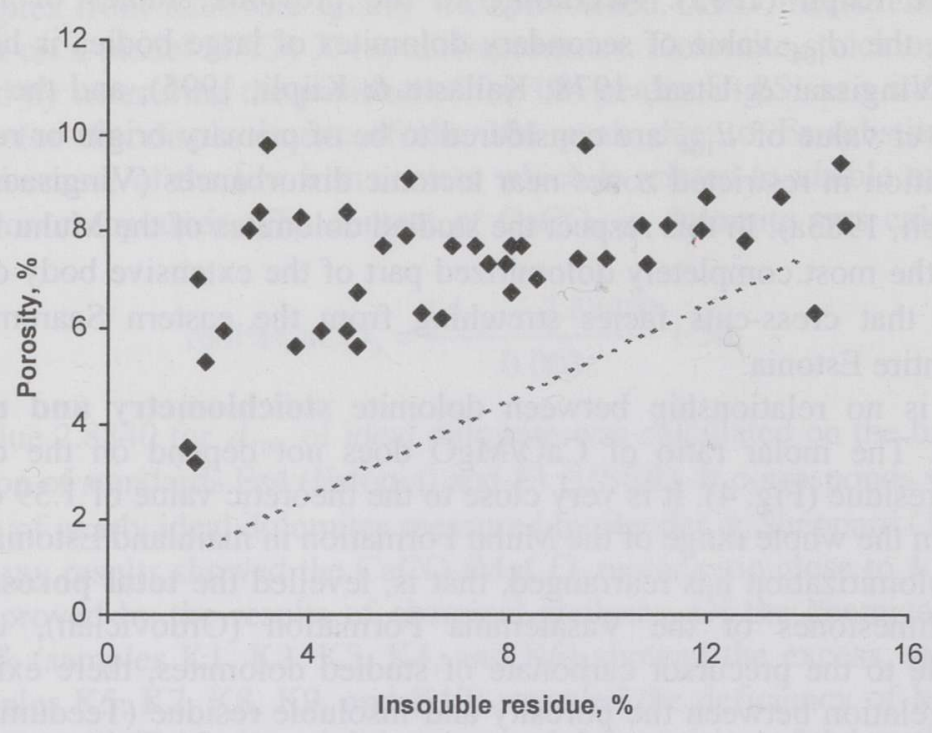

Fig. 5. Correlation of the total porosity and the insoluble residue content of the dolomites of the Koonga deposit. Analytical data of the exploration report (Remmel, 1974). Dashed line shows the generalized correlation of porosity and insoluble residue content of limestones of the Vasalemma deposit (after Teedumäe, 1988).

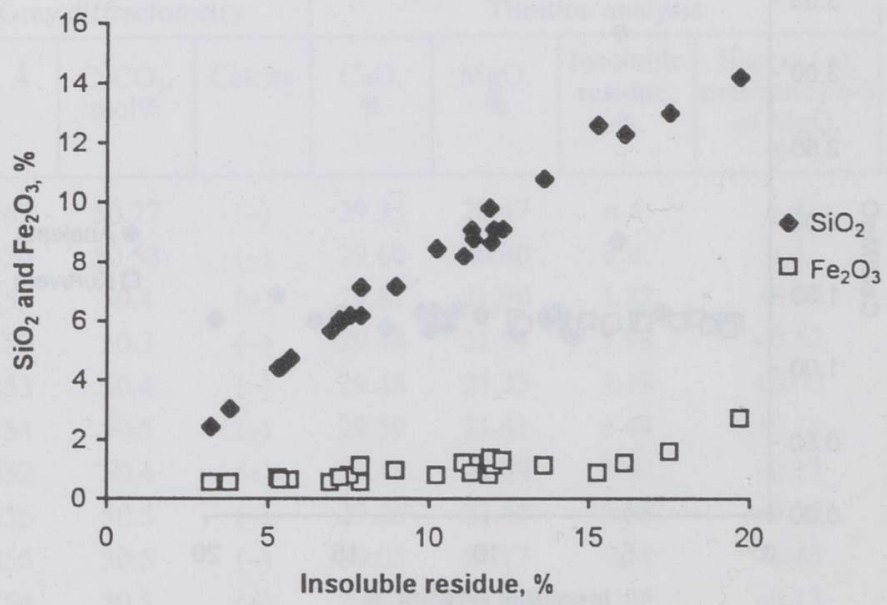

Fig. 6. Correlation of the $\mathrm{SiO}_{2}$ and $\mathrm{Fe}_{2} \mathrm{O}_{3}$ contents of the dolomites of the Anelema deposit. Chemical analyses of the exploration report (Korbut, 1989). 
The content of insoluble residue positively correlates with the content of $\mathrm{SiO}_{2}$ (Fig. 6), proving the suggestion of Jürgenson (1988, pp. 93-94) that the silt fraction of quartz was dominating in the composition of terrigenous material brought into the northern and northeastern parts of the "Baltic Gulf" during the Jaagarahu Age.

The content of Fe-compounds is low in all types of dolomites (Fig. 6). A weak trend towards its growth is observable from the content of insoluble residue above $10 \%$.

\section{DISCUSSION ON ASPECTS OF DOLOMITIZATION}

The nearly stoichiometric character of the dolomites of the Muhu Formation suggests their formation in the most favourable conditions for complete dolomitization. What could they have been?

In Estonia the Ordovician-Silurian rocks under the Devonian cover are dolomitized as deep as 40-50 m, and the zone of dolomitization extends along the strike as far as $40 \mathrm{~km}$ northwards of the boundary of the present distribution of the Devonian (Kiipli, 1983b). The source of magnesium has supposedly been the Devonian sediments (Jürgenson, 1970), the hypersaline lagoonal waters of the Devonian basin (Vishnyakov, 1956), or mixed fresh ground water and marine water of the Devonian basin (Kiipli, 1983b).

The influence of the Silurian sea water on the formation of the Muhu dolomites cannot be excluded (Kiipli, 1984). These, primarily calcareous shoal deposits of the Jaagarahu Age were bathed by sea water during and after deposition, being meanwhile, during the sedimentation break at the end of the age, also exposed to erosion. The palaeokarst cavities devoid of small idiomorphous crystals, which are met in some drill cores (around Uulu) on the corroded surface of the SilurianDevonian boundary, suggest that the dolomitization process might have almost ended even before the early Devonian subareal period.

As normal or modified (mixed meteoric-marine) sea water is supposed to be an important dolomitizing agent supplying enough $\mathrm{Mg}^{2+}$ for massive dolomitization in near-surface settings (e.g. Kruger \& Simo, 1994), special longterm hydrodynamic conditions are required. At low temperatures the time may be the key factor, so that sea water will become a major dolomitizing fluid only where stable circulation systems can drive it through carbonate platforms for many, up to millions of years (Hardie, 1987). The slow sedimentation rate could allow enough time for magnesium to diffuse into pore waters. It is supposed that in some cases the high alkalinity produced by organic matter decomposition through sulphate reducing bacteria, combined with the availability of magnesium, could have led to dolomite supersaturation in pore waters and to the replacement of the precursor calcium carbonate (Bernasconi, 1994).

The cyclicity of the evolution of the Baltic Basin (Nestor \& Einasto, 1997) suggests that sea water and mixed sea water as a major dolomitizing medium were 
pumped through Silurian sediments and rocks during rises and falls in relative sea level both in the Silurian and Devonian. The climate was favouring massive dolomitization, whereas in the Silurian (Nestor \& Einasto, 1997) as well as in the Devonian (Kurshs, 1992, pp. 152-155) the Baltic Basin was definitely situated in tropical latitudes. As shallow-marine tropical carbonates are predominantly composed of aragonite and calcite with high $\mathrm{Mg}$ concentrations (Tucker \& Wright, 1990, pp. 365-396), in early diagenetic dolomítization some $\mathrm{Mg}$ might have been derived from components of biogenic origin (e.g. skeletons). It is possible that once the conditions of initial growth had been satisfied, the subsequent growth of the dolomite lattice required less strict conditions and dolomitization might proceed under varying hydrochemical conditions and rates (Sibley et al., 1994), in all probability due to connate (relic) sea water and other subsurface waters even in the post-Devonian.

The formation of well-ordered, close to ideal dolomites of the Muhu Formation, originating from the shallow-water calcareous sediments, results from the balanced system of all factors concerned - sedimentation, burial, climate, eustatic fluctuations and so on, which existed during a sufficiently long time span (millions of years), providing a suitable environment for dolomitization. In all likelihood, the dolomitization of the Muhu Formation began in the Silurian, soon after the deposition and ended in the early post-Devonian. A more exact timing of the dolomitization process is not possible by any methods known so far.

The present state of knowledge confirms that in early stages the normal marine, and in later stages the mixed meteoric-marine water served as the main agents of dolomitization.

\section{CONCLUSIONS}

In mainland Estonia, the dolomites of the Muhu Formation originating from the shallow-water calcareous sediments represent the most completely dolomitized rocks of the extensive body of Silurian dolomites in Estonia that cross-cuts facies and depositional sequences.

The dolomitization is uniform throughout the Muhu Formation. The $\mathrm{CaO} / \mathrm{MgO}$ molar ratio and the crystal lattice of the Muhu dolomites are close to those of ideal dolomite, irrespective of the content of insoluble residue or the texture of rocks.

Most likely the process of dolomitization was long-lasting - from the Silurian to the post-Devonian, enabling total replacement of the precursor calcite. The low average value of porosity (6-9\%) is consistent with that of Palaeozoic massive replacement dolomites.

The reef, breccia, and especially flaggy interreef dolomites are the purest and hardest dolomites in Estonia and may find use in agriculture, glass manufacture, and building, while the low-argillaceous dolomite is suitable for agricultural and building purposes. 


\section{ACKNOWLEDGEMENTS}

The authors thank D. Kaljo and H. Nestor for helpful comments, T. Linkova for performing the chemical analyses, and P. Pärkma for the figures. Financial support was provided by the research project No. 140226 and partly by grant No. 2723 of the Estonian Science Foundation.

\section{REFERENCES}

Aaloe, A. 1970. Jaagarahu Stage. In Silur Éstonii (Kaljo, D., ed.), pp. 252-264. Valgus, Tallinn (in Russian).

Aaloe, A., Mark, E., Männil, R., Müürisepp, K. \& Orviku, K. 1958. Obzor stratigrafii paleozojskikh $i$ chetvertichnykh otlozhenij Éstonskoj SSR. Tallinn (in Russian).

Aaloe, A., Kaljo, D., Klaamann, E., Nestor, H. \& Einasto, R. 1976. Stratigraphical classification of the Estonian Silurian. ENSV TA Toim. Keem. Geol., 25, 1, 38-45 (in Russian).

Bernasconi, S. M. 1994. Geochemical and microbial controls on dolomite formation in anoxic environments: a case study from the Middle Triassic (Ticino, Switzerland). Contrib. Sediment., 19.

Hardie, L. A. 1987. Dolomitization: a critical view of some current views. J. Sedim. Petrol., 57, 1, $176-178$.

Jürgenson, E. 1970. Distribution and composition of the terrigenous material. Secondary alternation of rocks. In Silur Éstonii (Kaljo, D., ed.), pp. 68-102. Valgus, Tallinn (in Russian).

Jürgenson, E. 1988. Osadkonakoplenie v silure Pribaltiki. Valgus, Tallinn (in Russian).

Kajak, H., Remmel, P., Saadre, T., Puura, V., Kajak, K. \& Kala, E. 1972. Otchet o kompleksnoj geologo-gidrogeologicheskoj s"emki srednego masshtaba yugo-zapadnoj chasti Éstonii (list O-34 XVII). Estonian Geological Fund, unpublished report No. 3212 (in Russian).

Kallaste, T. \& Kiipli, T. 1995. Discrete dolomite phases in carbonate rocks: results of the mathematical treatment of X-ray diffraction peaks. Proc. Estonian Acad. Sci. Geol., 44, 4, 211-220.

Kiipli, T. 1983a. Dolomites of the Estonian Middle Ordovician Väo Formation. ENSV TA Toim. Geol., 32, 2, 60-67 (in Russian).

Kiipli, T. 1983b. On the genesis of Ordovician and Silurian dolomites at the contact with Devonian deposits. ENSV TA Toim. Geol., 32, 3, 110-117 (in Russian).

Kiipli, T. 1984. Genezis $i$ rasprostranenie promyshlennykh zalezhej maloprimesnykh izvestnyakov $i$ dolomitov v Éstonskoj SSR. Avtoreferat kandidatskoj dissertatsii. Tallinn (in Russian).

Korbut, S. 1989. Otchet o dorazvedke mestorozhdeniya dolomitov Anelema. Estonian Geological Fund, unpublished report No. 4954 (in Russian).

Korbut, S. 1991. Aruanne Kurevere ehituskivimaardla detailuuringust Läänemaal. Estonian Geological Fund, unpublished report No. 4564.

Korbut, S. 1993a. Aruanne Kurevere dolomiidilevila geoloogilisest uuringust aktsiaseltsile Nordkalk. Estonian Geological Fund, unpublished report No. 4671.

Korbut, S. 1993b. Tarva dolomiidimaardla uuringust Pärnu Teedevalitsusele. Estonian Geological Fund, unpublished report No. 4693.

Kruger, J. M. \& Simo, J. A. 1994. Pervasive dolomitization of a subtidal carbonate ramp, Silurian and Devonian, Illinois Basin, USA. Spec. Publ. Int. Ass. Sediment., 21, 387-388.

Kurshs, V. M. 1992. Devonskoe terrigennoe osadkonakoplenie na Glavnom devonskom pole. Zinatne, Riga (in Russian). 
Lodjak, T. 1981. Otchet o poiskovo-revizionnykh pabotakh stekol'nykh dolomitov. Estonian Geological Fund, unpublished report No. 3878 (in Russian).

Luha, A. 1930. Über Ergebnisse stratigraphischer Untersuchungen im Gebiete der Saaremaa-(Ösel-) Schichten in Eesti (Unterösel und Eurypterusschichten). Acta Comment. Univ. Tartuensis, A18, 6 .

Luha, A. 1933. Eesti geoloogiline koostis. In Eesti Entsüklopeedia, Vol. 2, pp. 528-535.

Luha, A. 1946. Eesti NSV maavarad. Rakendusgeoloogiline kokkuvõtlik ülevaade. Teaduslik Kirjandus, Tartu.

Nestor, H. 1995. Comments to the modified Silurian correlation chart of Estonia and Latvia. Geologija, 17, 88-95.

Nestor, H. 1997. Jaagarahu Stage. In Geology and Mineral Resources of Estonia (Raukas, A. \& Teedumäe, A., eds.), pp. 99-101. Estonian Academy Publishers, Tallinn.

Nestor, H. \& Einasto, R. 1997. Ordovician and Silurian carbonate sedimentation basin. In Geology and Mineral Resources of Estonia (Raukas, A. \& Teedumäe, A., eds.), pp. 192-204. Estonian Academy Publishers, Tallinn.

Nestor, V. \& Nestor, H. 1991. Dating of the Wenlock carbonate sequences in Estonia and stratigraphic breaks. Proc. Estonian Acad. Sci. Geol., 40, 2, 50-60.

Purser, B. H., Tucker, M. E. \& Zenger, D. H. 1994. Problems, progress and future research concerning dolomites and dolomitization. Spec. Publ. Int. Ass. Sediment., 21, 3-20.

Reeder, R. J. \& Sheppard, C. E. 1984. Variation of lattice parameters in some sedimentary dolomites. Amer. Mineralogist, 69, 520-527.

Remmel, S. 1968. Otchet po poiskam izvestnyakov i dolomitov povyshennoj prochnosti. Estonian Geological Fund, unpublished report No. 2972 (in Russian).

Remmel, S. 1969. Otchet o detal'noj razvedke dolomitov povyshennoj prochnosti na mestorozhdenii Anelema. Estonian Geological Fund, unpublished report No. 3036 (in Russian).

Remmel, S. 1974. Koonga dolomiidimaardla detailsetest uuringutöödest. Estonian Geological Fund, unpublished report No. 3315.

Resheniya..., 1987. Resheniya mezhvedomstvennogo stratigraficheskogo soveshchaniya po ordoviku i siluru Vostochno-Evropeiskoj platformy $1984 \mathrm{~g}$. s regional'nymi stratigraficheskimi skhemami. Leningrad (in Russian).

Sibley, D. F., Nordeng, S. H. \& Borkovski, M. L. 1994. Dolomitization kinetics in hydrothermal bombs and natural settings. J. Sediment. Res., A64, 630-637.

Teedumäe, A. 1983. Karbonatnye porody Éstonskoj SSR i ikh ratsional'noe ispol'zovanie. Avtoreferat kandidatskoj dissertatsii. Leningrad (in Russian).

Teedumäe, A. 1988. Peculiarities of the correlation of physical and mechanical properties of the limestones in the Vasalemma deposit. Proc. Estonian Acad. Sci. Geol., 37, 1, 18-25 (in Russian).

Teedumäe, A. 1992. Possibilities of the application of carbonate rocks of the Raikküla Formation (Silurian, Estonia). Proc. Estonian Acad. Sci. Geol., 41, 2, 63-72.

Teedumäe, A. 1996. Carbonate rocks of the Adavere Stage and possibilities of their utilization (Silurian, Estonia). Proc. Estonian Acad. Sci. Geol., 45, 1, 22-33.

Tucker, M. E. \& Wright, V. P. 1990. Carbonate Sedimentology. Blackwell Scientific, London.

Tuuling, T. 1993. Aruanne ehituskivi otsingu-hinnangutöödest Lihula ümbruses Läänemaal. Estonian Geological Fund, unpublished report No. 4676.

Vingisaar, P. \& Utsal, K. 1978. About the rockforming carbonate minerals of Paleozoic of Estonia. Sov. Geol., 12, 107-115 (in Russian).

Vishnyakov, S. G. 1956. Genetic types of dolomitic rocks in the northwestern margin of the Russian Platform. Tr. geol. inst. AN SSSR, 4, 209-255 (in Russian). 


\title{
MUHU KIHISTU (SILUR) DOLOMIIDID EESTI MANDRIOSAS: DOLOMIIDISTUMISE ASPEKTID, OMADUSED JA KASUTAMISE PERSPEKTIIVID
}

\author{
Aada TEEDUMÄE, Tarmo KIIPLI ja Toivo KALLASTE
}

On uuritud Muhu kihistu viie litoloogiliselt erineva dolomiiditüübi ainelist koostist, kivimilisi omadusi ja nende seoseid dolomiidistumisega. Kõigis kivimitüüpides on mineraal dolomiit nii koostise $(\mathrm{CaO} / \mathrm{MgO}$ ca 1,39$)$ kui ka kristallvõre aatomtasandite vahekauguse väärtuse $\left(d_{104} 2,8850-2,8856 \AA\right)$ poolest ligilähedane ideaaldolomiidile. Ideaalilähedust on seni täheldatud vaid primaarsete ja tektooniliste lõhedega seonduvate dolomiitide puhul. Muhu kihistu dolomiidid on Siluri läbilõikes kõige täiuslikumalt dolomiidistunud. Nende omadusi on käsitletud rakenduslikust seisukohast ja antud sellekohane hinnang.

\section{ДОЛОМИТЫ МУХУСКОЙ СВИТЫ (СИЛУР) НА МАТЕРИКОВОЙ ЧАСТИ ЭСТОНИИ: АСПЕКТЫ ДОЛОМИТИЗАЦИИ, СВОЙСТВА И ПЕРСПЕКТИВЫ ИСПОЛЬЗОВАНИЯ}

\author{
Аада ТЭЭДУМЯЭ, Тармо КИЙПЛИ и Тойво КАЛЛАСТЕ
}

Изучены свойства пяти литологически разных типов доломитов, слагающих мухускую свиту, и их связанность с доломитизацией. Вещественный состав $(\mathrm{CaO} / \mathrm{MgO}$ около 1,39$)$ и величина межплоскостного расстояния $\left(d_{104} 2,8850-2,8856 \AA\right)$ всех изученных типов доломитов близки к идеальным. Ранее сходные значения были установлены у первичных доломитов и доломитов вблизи тектонических трещин. Вторичные доломиты мухуской свиты обладают самой совершенной структурой среди доломитов всего силурийского разреза. Оценены перспективы использования доломитов в качестве карбонатного сырья. 